Article

\title{
Catalytic Characteristics of New Antibacterials Based on Hexahistidine-Containing Organophosphorus Hydrolase
}

\author{
Olga Maslova * (D), Aysel Aslanli, Nikolay Stepanov, Ilya Lyagin (D) and Elena Efremenko* \\ Faculty of Chemistry, Lomonosov Moscow State University, Moscow 119991, Russia; \\ ayselaslanli@mail.ru (A.A.); na.stepanov@gmail.com (N.S.); lyagin@mail.ru (I.L.) \\ * Correspondence: olga.maslova.rabota@gmail.com (O.M.); elena_efremenko@list.ru (E.E.); \\ Tel.: +7-977-3093977 (O.M.); +7-495-9393170 (E.E.)
}

Received: 30 August 2017; Accepted: 11 September 2017; Published: 14 September 2017

\begin{abstract}
Catalytic characteristics of hexahistidine-containing organophosphorus hydrolase ( $\mathrm{His}_{6}-\mathrm{OPH}$ ) and its enzyme-polyelectrolyte complexes with poly-L-glutamic acid or poly-L-aspartic acid $\left(\mathrm{His}_{6}-\mathrm{OPH} / \mathrm{PLD}_{50}\right)$, hydrolyzing organophosphorous compounds, and $\mathrm{N}$-acyl homoserine lactones were studied in the presence of various antibiotics (ampicillin, gentamicin, kanamycin, and rifampicin). The antibiotics at concentrations below $1 \mathrm{~g} \cdot \mathrm{L}^{-1}$ had a negligible inhibiting effect on the $\mathrm{His}_{6}-\mathrm{OPH}$ activity. Mixed inhibition of $\mathrm{His}_{6}-\mathrm{OPH}$ was established for higher antibiotic concentrations, and rifampicin was the most potent inhibitor. Stabilization of the $\mathrm{His}_{6}-\mathrm{OPH}$ activity was observed in the presence of antibiotics at a concentration of $0.2 \mathrm{~g} \cdot \mathrm{L}^{-1}$ during exposure at $25-41{ }^{\circ} \mathrm{C}$. Molecular docking of antibiotics to the surface of $\mathrm{His}_{6}$-OPH dimer revealed the antibiotics binding both to the area near active centers of the enzyme subunits and to the region of contact between subunits of the dimer. Such interactions between antibiotics and $\mathrm{His}_{6}-\mathrm{OPH}$ were verified with Fourier-transform infrared (FTIR) spectroscopy. Considering all the results of the study, the combination of $\mathrm{His}_{6}-\mathrm{OPH} / \mathrm{PLD}_{50}$ with $\beta$-lactam antibiotic ampicillin was established as the optimal one in terms of exhibition and persistence of maximal lactonase activity of the enzyme.
\end{abstract}

Keywords: hexahistidine-containing organophosphorus hydrolase; antibiotic; ampicillin; gentamicin; kanamycin; rifampicin; inhibition; enzyme stability

\section{Introduction}

The mechanisms of antibiotic resistance formation in pathogens have been rather well studied to date [1]. Development and application of combinations of antimicrobials is one of the possible solutions to the antibiotic resistance problem. This approach utilizes different active compounds acting via different routes towards target microorganisms. Thus, efficient practical application was reported for antibiotics combined with inhibitors of the pathogen's enzymes that hydrolyze those antibiotics, or with compounds inhibiting the efflux pumps, so that accumulation of the drug within the bacterial cells was facilitated [2].

The antibiotic resistance of pathogens is greatly increased when the latter are in high-concentration cell populations, including biofilms [3], which is an additional difficulty in treating such infections. This increase in resistance is due to the quorum sensing mechanism of the bacteria [4]. This complex protective mechanism leads to an essential increase in antibiotic resistance of microorganisms in concentrated populations (by a factor of 10 to 200 compared to that of low concentration cultures) [5].

Many gram-negative bacterial species are known pathogens causing death in animals and plants. Many of these species are capable of quorum sensing, and $N$-acyl homoserine lactones synthesized by these cells are the inductors of this mechanism. 
An efficient approach to control the antibiotic resistance of pathogenic bacterial cultures via combining the known antibiotics with enzymes destroying the signal molecules of the quorum sensing mechanism (in particular, $N$-acyl homoserine lactones) has been suggested $[6,7]$. This approach has already been successfully demonstrated in agrobiotechnology and aquaculture [8].

Destruction of $\mathrm{N}$-acyl homoserine lactones is aimed at preventing the bacterial cells from transitioning into the resistant state [9]. This ensures more effective action of antimicrobials on the pathogen cells, thus allowing a reduction of the required antibiotic dosage.

Enzymatic destruction of $\mathrm{N}$-acyl homoserine lactones can be efficiently achieved with lactonases $[6,10,11]$. To date, many studies of the catalytic impact of various lactonases have been performed, and the structure of many such agents have been established [12-14]. The role of the amino acid residues in the enzyme molecule's structure, as well as that of the substrate and the environment on the level of lactonase activity, was established [15]. However, the synthesis techniques developed so far for lactonase production, as well as methods of lactonase purification and stabilization, cannot ensure the feasibility of practical application of these enzymes.

However, there are other enzymes with lactonase activity [16], including the hexahistidine-containing organophosphorus hydrolase $\left(\mathrm{His}_{6}-\mathrm{OPH}\right.$; sequence of parent enzyme is available at UniProtKB P0A434). This enzyme, having a $\mathrm{pH}$ optimum at 10.5, is produced by recombinant E. coli cells under conditions optimized in a previous study [17]. This enzyme is well studied in terms of structure, catalytic characteristics, and mechanism of action, which ensures hydrolysis of a great variety of organophosphorous compounds and $N$-acyl homoserine lactones [16,18]. It is known that the enzyme can be stabilized by producing relatively inexpensive enzyme-polyelectrolyte complexes (EPC) containing the $\mathrm{His}_{6}-\mathrm{OPH}$ and a polyanionic polymer [19]. The complexes were efficiently applied in vivo, where the $\mathrm{pH}$ in the blood stream was close to 7.5 .

The prospects for developing combined preparations based on combinations of antibiotics with $\mathrm{His}_{6}-\mathrm{OPH}$ and/or EPC of this enzyme are obvious. However, since the possible influence of various antibiotics on the enzymatic activity of $\mathrm{His}_{6}$-OPH has not been researched so far, this paper focused on studying this influence. Thus, we combined antibiotics characterized by different chemical structures and various $\mathrm{His}_{6}$-OPH-based enzymatic preparations and determined the catalytic properties of the latter in such systems.

\section{Results}

\subsection{Studies of Catalytic Properties of $\mathrm{His}_{6}-\mathrm{OPH}$ and Its Polyelectrolyte Complexes in the Presence of Antibiotics}

It was established that antibiotics with concentrations in excess of $8 \mathrm{~g} \cdot \mathrm{L}^{-1}$ inhibited the $\mathrm{His}_{6}$-OPH enzymatic activity (Table 1) with mixed inhibition evaluated using the Dixon technique (Figure 1).

The maximum values of $V_{\max } \cdot E_{0}{ }^{-1}$ in the presence of antibiotics were observed for $\mathrm{His}_{6}-\mathrm{OPH}$ in polyelectrolyte complexes with poly-L-aspartic acid $\left(\mathrm{PLD}_{50}\right)$. Therefore, the inhibition constants $K_{\mathrm{ic}}$ and $K_{\mathrm{iu}}$ were greater in this case by a factor of 1.7-3.4 compared to the native $\mathrm{His}_{6}-\mathrm{OPH}$. In contrast to this, the values of $K_{\mathrm{ic}}$ and $K_{\mathrm{iu}}$ for the EPC based on poly-L-glutamic acid (PLE50) were the same as in the case of $\mathrm{His}_{6}-\mathrm{OPH}$ or smaller by a factor of 1.5-2.4.

On average over all enzyme preparations, an inhibitory potency via competitive inhibition increased in a row: ampicillin $\approx$ gentamicin $<$ kanamycin $<$ rifampicin. Analogously, uncompetitive inhibitory potency increased in a row: ampicillin $<$ gentamicin $<$ kanamycin $<$ rifampicin. Since uncompetitive inhibition usually prevailed over a competitive one, inhibitors' potency increased in a row: ampicillin < gentamicin $<$ kanamycin $<$ rifampicin. 
Table 1. Catalytic constants of hexahistidine-containing organophosphorus hydrolase ( $\left.\mathrm{His}_{6}-\mathrm{OPH}\right)$ and its polyelectrolyte complexes with poly-L-aspartic acid $\left(\mathrm{His}_{6}-\mathrm{OPH} / \mathrm{PLD}_{50}\right)$ and poly-L-glutamic acid ( His $\left._{6}-\mathrm{OPH} / \mathrm{PLE}_{50}\right)$ during Paraoxon hydrolysis in the presence of various antibiotics. $K_{\mathrm{ic}}$ and $K_{\mathrm{iu}}$ are competitive and uncompetitive inhibition constants, respectively. Apparent constants $K_{\mathrm{m}}$ app and $V_{\max }{ }^{\text {app }}$ were calculated in the presence of antibiotics. EPC $=$ enzyme-polyelectrolyte complexes.

\begin{tabular}{|c|c|c|c|c|c|c|}
\hline Inhibitor & Enzyme or EPC & $K_{\text {ic }}(\mathrm{mM})$ & $K_{\mathrm{iu}}(\mathrm{mM})$ & $K_{\mathrm{m}}(\mu \mathrm{M})$ & $V_{\max } \cdot E_{0}^{-1}\left(\mathrm{~s}^{-1}\right)$ & $V_{\max } \cdot E_{0}^{-1} \cdot K_{\mathrm{m}}^{-1}\left(10^{6} \mathrm{~s}^{-1} \cdot \mathrm{M}^{-1}\right)$ \\
\hline \multirow{3}{*}{-} & $\mathrm{His}_{6}-\mathrm{OPH}$ & - & - & $10.5 \pm 2.2$ & $5040 \pm 340$ & $480 \pm 133$ \\
\hline & $\mathrm{His}_{6}-\mathrm{OPH} / \mathrm{PLD}_{50}$ & - & - & $12.1 \pm 1.0$ & $5240 \pm 140$ & $433 \pm 47$ \\
\hline & $\mathrm{His}_{6}-\mathrm{OPH} / \mathrm{PLE}_{50}$ & - & - & $15.0 \pm 2.1$ & $4880 \pm 240$ & $325 \pm 62$ \\
\hline \multirow{3}{*}{ Ampicillin } & $\mathrm{His}_{6}-\mathrm{OPH}$ & $229 \pm 15$ & $72 \pm 15$ & $18.2 \pm 3.8$ & $3360 \pm 230$ & $185 \pm 51$ \\
\hline & $\mathrm{His}_{6}-\mathrm{OPH} / \mathrm{PLD}_{50}$ & $515 \pm 14$ & $241 \pm 20$ & $14.6 \pm 1.2$ & $4450 \pm 120$ & $305 \pm 33$ \\
\hline & $\mathrm{His}_{6}-\mathrm{OPH} / \mathrm{PLE}_{50}$ & $146 \pm 7$ & $48 \pm 7$ & $28.5 \pm 4.0$ & $2760 \pm 140$ & $97 \pm 19$ \\
\hline \multirow{3}{*}{ Gentamicin } & $\mathrm{His}_{6}-\mathrm{OPH}$ & $264 \pm 18$ & $61 \pm 13$ & $18.9 \pm 4.0$ & $2230 \pm 150$ & $118 \pm 33$ \\
\hline & $\mathrm{His}_{6}-\mathrm{OPH} / \mathrm{PLD}_{50}$ & $377 \pm 10$ & $109 \pm 9$ & $17.5 \pm 1.4$ & $4390 \pm 120$ & $251 \pm 27$ \\
\hline & $\mathrm{His}_{6}-\mathrm{OPH} / \mathrm{PLE}_{50}$ & $162 \pm 8$ & $41 \pm 6$ & $30.2 \pm 4.2$ & $3250 \pm 160$ & $108 \pm 20$ \\
\hline \multirow{3}{*}{ Kanamycin } & $\mathrm{His}_{6}-\mathrm{OPH}$ & $72 \pm 5$ & $62 \pm 13$ & $11.3 \pm 2.4$ & $1340 \pm 90$ & $119 \pm 33$ \\
\hline & $\mathrm{His}_{6}-\mathrm{OPH} / \mathrm{PLD}_{50}$ & $142 \pm 4$ & $23 \pm 2$ & $30.6 \pm 2.5$ & $4700 \pm 130$ & $154 \pm 17$ \\
\hline & $\mathrm{His}_{6}-\mathrm{OPH} / \mathrm{PLE}_{50}$ & $44 \pm 2$ & $26 \pm 4$ & $21.1 \pm 3.0$ & $1340 \pm 70$ & $64 \pm 12$ \\
\hline \multirow{3}{*}{ Rifampicin } & $\mathrm{His}_{6}-\mathrm{OPH}$ & $29 \pm 2$ & $26 \pm 5$ & $11.2 \pm 2.3$ & $1750 \pm 120$ & $156 \pm 43$ \\
\hline & $\mathrm{His}_{6}-\mathrm{OPH} / \mathrm{PLD}_{50}$ & $79 \pm 2$ & $10 \pm 1$ & $39.1 \pm 3.2$ & $3580 \pm 100$ & $92 \pm 10$ \\
\hline & $\mathrm{His}_{6}-\mathrm{OPH} / \mathrm{PLE}_{50}$ & $32 \pm 2$ & $15 \pm 2$ & $23.7 \pm 3.3$ & $3250 \pm 160$ & $137 \pm 26$ \\
\hline
\end{tabular}
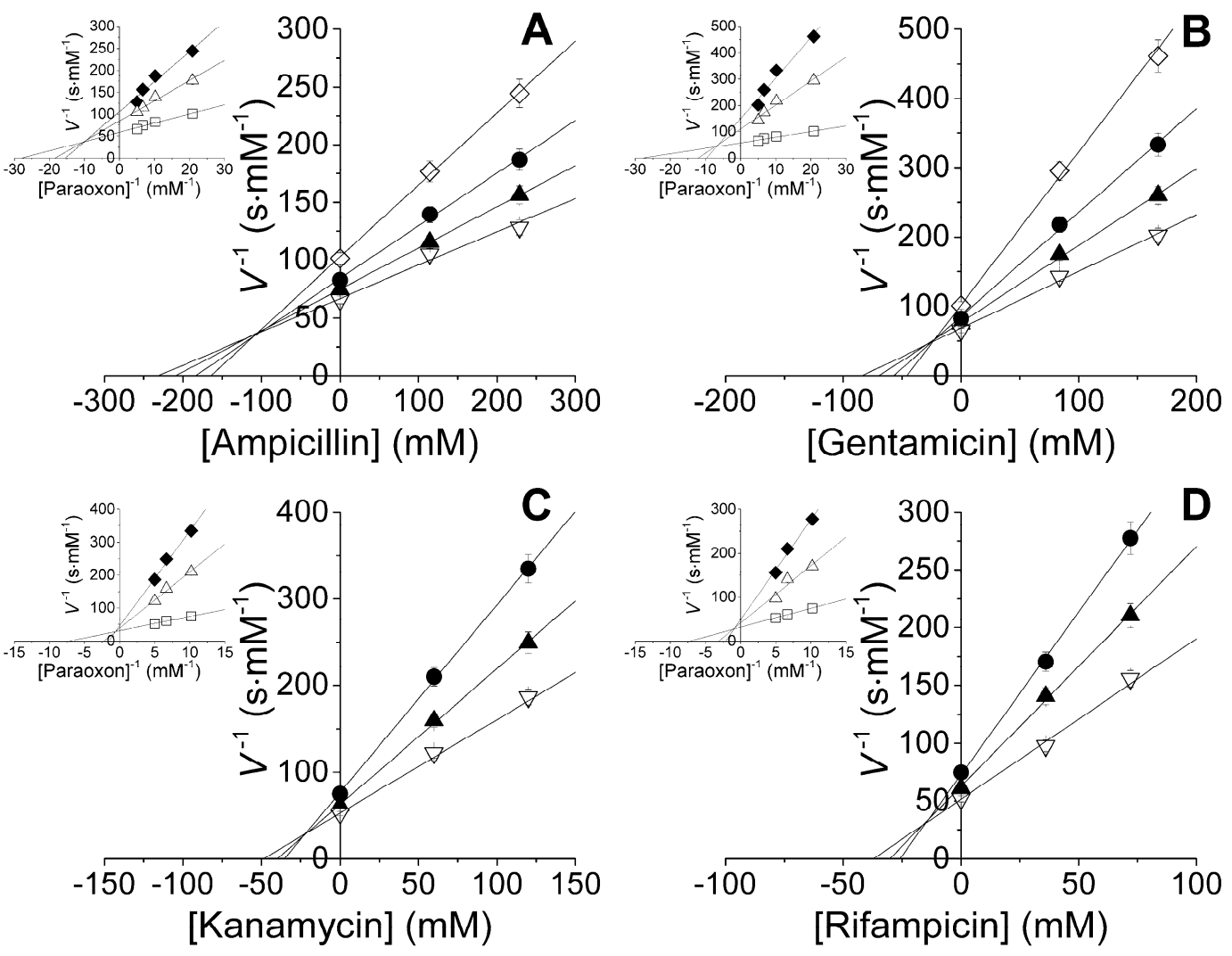

Figure 1. Mixed inhibition of $\mathrm{His}_{6}-\mathrm{OPH}$ by various antibiotics: (A) ampicillin $(-0 ; \Delta-115$ and $\square-229 \mathrm{mM})$; (B) gentamicin $(\checkmark-0 ; \Delta-84$ and $\square-168 \mathrm{mM}) ;(\mathbf{C})$ kanamycin $(\diamond-0 ; \Delta-60$ and $\square-120 \mathrm{mM})$; and (D) rifampicin $(\checkmark-0 ; \Delta-36$ and $\square-72 \mathrm{mM})$. Paraoxon concentration was $0.05(\diamond)$, $0.1(\bullet), 0.15(\mathbf{\Delta})$ and $0.2 \mathrm{mM}(\nabla)$. 


\subsection{Molecular Docking of Antibiotics to the $\mathrm{His}_{6}$-OPH Dimer and Fourier-Transform Infrared (FTIR) Spectroscopy}

Using the molecular docking of antibiotics to the $\mathrm{His}_{6}-\mathrm{OPH}$ dimer at $\mathrm{pH} 7.5$ and 10.5, the models for the most probable modes of interaction between the molecules were obtained (Figures 2-5). In addition to the binding of antibiotics directly to the active center pocket of the enzyme, interaction with other parts of the dimer surface was observed. In particular, the region of contact between two identical subunits of the dimer enzyme molecule was preferred.

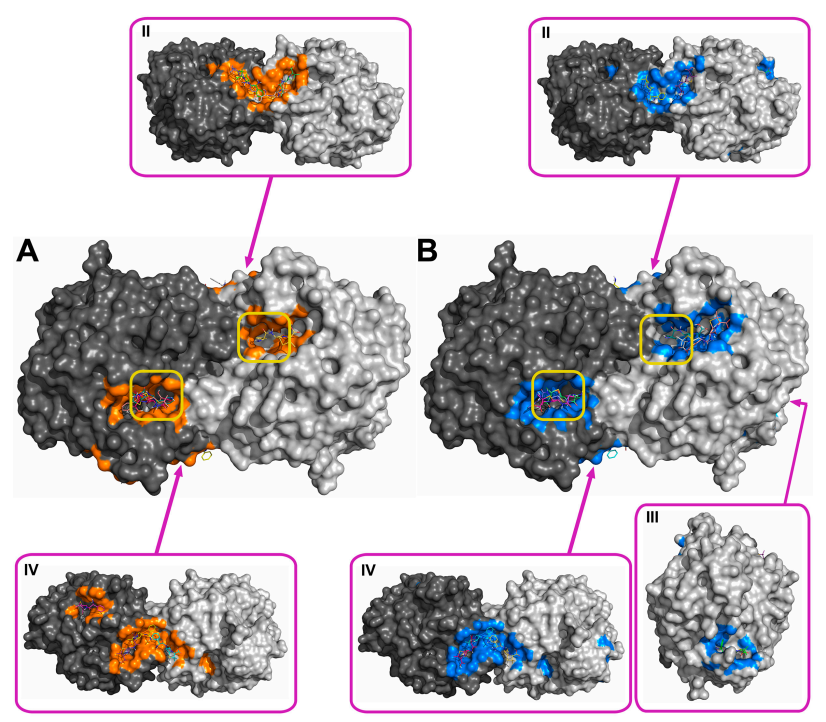

Figure 2. Supposed localization of the domains for binding ampicillin at pH 7.5 (A) and 10.5 (B). The two subunits of the $\mathrm{His}_{6}$-OPH homodimer are colored differently (grey and dark grey). Atoms on the surface of $\mathrm{His}_{6}-\mathrm{OPH}$ located within $4 \AA$ of any atom of ampicillin, as well as the corresponding molecular surface, are colored orange (A) or marine (B). Entrances to the active sites of the $\mathrm{His}_{6}-\mathrm{OPH}$ dimer are highlighted with yellow boxes. Magenta boxes show clockwise a $\mathrm{His}_{6}$-OPH dimer molecule when viewed from above (II), from the right (III), and from below (IV) (relative to the side where the active sites are located).

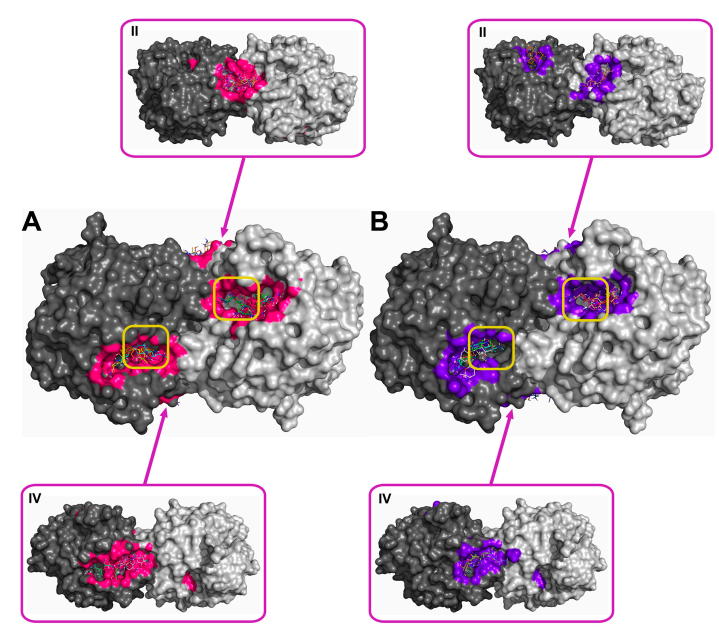

Figure 3. Supposed localization of the domains for binding gentamicin at pH 7.5 (A) and 10.5 (B). The two subunits of the $\mathrm{His}_{6}-\mathrm{OPH}$ homodimer are colored differently (grey and dark grey). Atoms on the surface of $\mathrm{His}_{6}-\mathrm{OPH}$ located within $4 \AA$ of any atom of gentamicin, as well as the corresponding molecular surface, are colored pink (A) or purple (B). Entrances to the active sites of the $\mathrm{His}_{6}-\mathrm{OPH}$ dimer are highlighted with yellow boxes. Magenta boxes show clockwise a $\mathrm{His}_{6}$-OPH dimer molecule when it is viewed from above (II) and below (IV) (relative to the side where the active sites are located). 


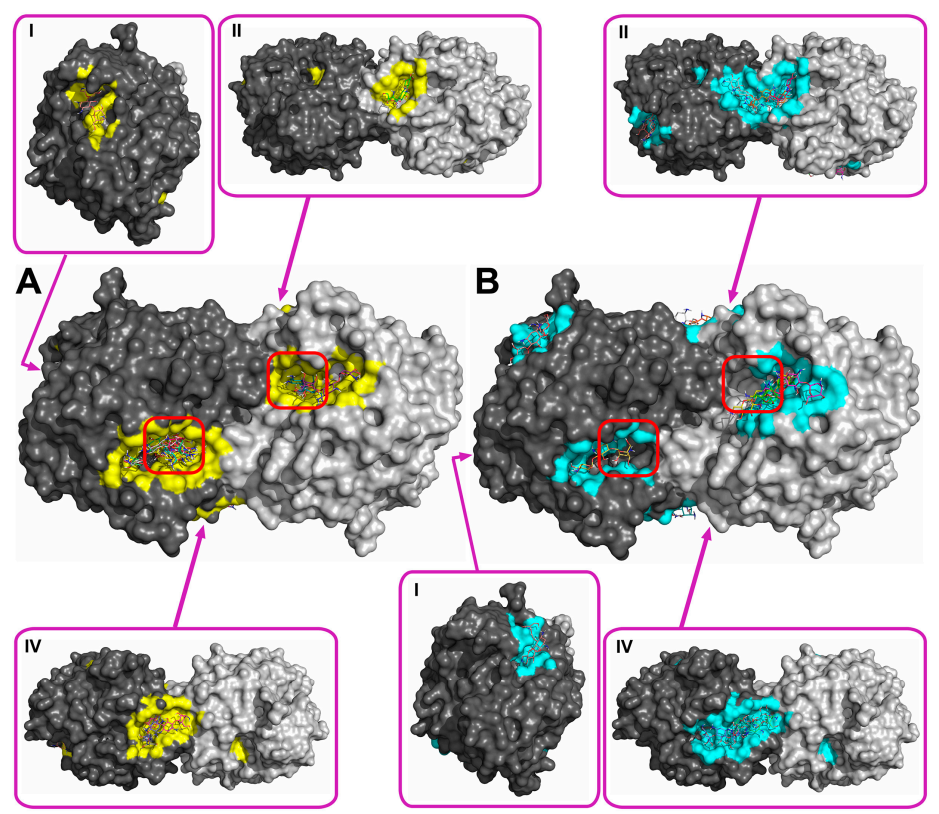

Figure 4. Supposed localization of the domains for binding kanamycin at pH 7.5 (A) and 10.5 (B). The two subunits of the $\mathrm{His}_{6}$-OPH homodimer are colored differently (grey and dark grey). Atoms on the surface of $\mathrm{His}_{6}-\mathrm{OPH}$ located within $4 \AA$ of any atom of kanamycin, as well as the corresponding molecular surface, are colored yellow (A) or cyan (B), respectively. Entrances to the active sites of the $\mathrm{His}_{6}-\mathrm{OPH}$ dimer are highlighted with red boxes. Magenta boxes show clockwise a His ${ }_{6}-\mathrm{OPH}$ dimer molecule when it is viewed from the left (I), from above (II), and from below (IV) (relative to the side where the active sites are located).

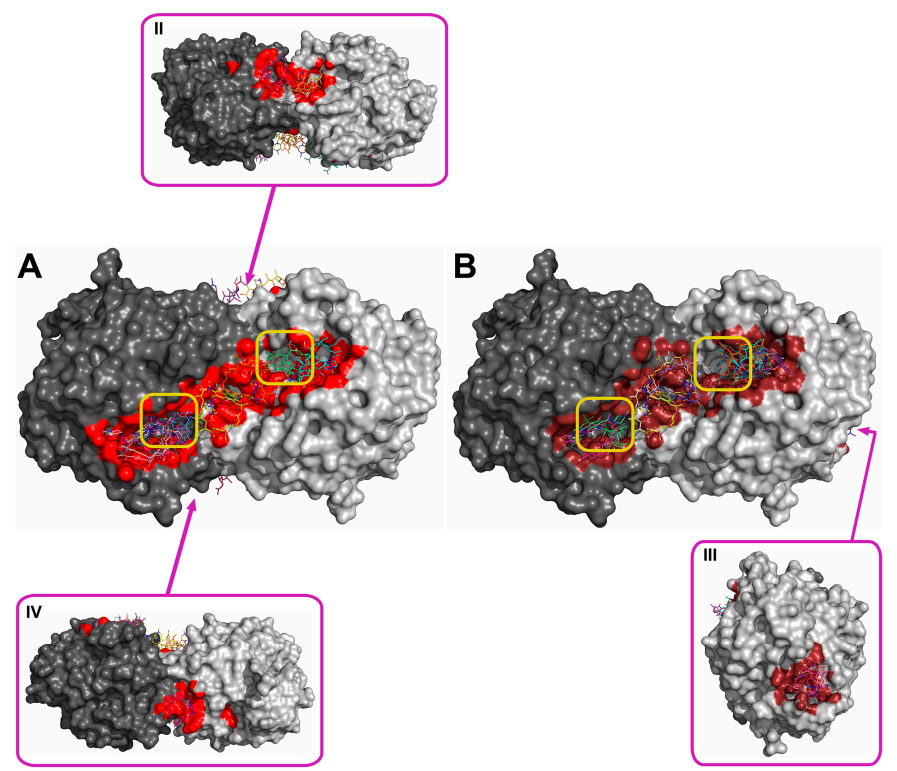

Figure 5. Supposed localization of the domains for binding rifampicin at $\mathrm{pH} 7.5$ (A) and 10.5 (B). The two subunits of the $\mathrm{His}_{6}$-OPH homodimer are colored differently (grey and dark grey). Atoms on the surface of $\mathrm{His}_{6}-\mathrm{OPH}$ located within $4 \AA$ of any atom of rifampicin, as well as the corresponding molecular surface, are colored red (A) or ruby (B), respectively. Entrances to the active sites of the $\mathrm{His}_{6}$-OPH dimer are highlighted with yellow boxes. Magenta boxes show clockwise a His 6 -OPH dimer molecule when it is viewed from above (II), from the right (III), and from below (IV) (relative to the side where the active sites are located). 
During computer simulation, an affinity function (i.e., an estimate of the minimum of potential energy during electrostatic and hydrophobic interactions, and hydrogen bonding between the ligand (antibiotic) and the receptor (enzyme)) was minimized (Table 2). Difference of energy values obtained at different $\mathrm{pH}$ was statistically non-significant for kanamycin and rifampicin $(p=0.062$ and 0.601 , respectively), according to one-way analysis of variance (ANOVA). So, binding of such antibiotics seems to be independent of $\mathrm{pH}$. In contrast, there was statistical differences for the same parameters of ampicillin and gentamicin ( $p=0.027$ and 0.002 , respectively). Moreover, binding of both antibiotics is stronger at $\mathrm{pH} 7.5$.

Testing of different antibiotic pairs at $\mathrm{pH} 7.5$ or 10.5 with one-way ANOVA reveals only two pairs with statistically non-significant differences: gentamicin vs. kanamycin (at both $\mathrm{pH}, p \geq 0.191$ ), and ampicillin vs. rifampicin (at $\mathrm{pH} 7.5, p=0.054$ ). Difference of all other pairs was statistically significant $(p \leq 0.038)$. Therefore, the lowest values of binding energies were for rifampicin at both $\mathrm{pH}$ levels and for ampicillin at $\mathrm{pH} 7.5$ (Table 2). Highest values of binding energies were for kanamycin and gentamicin.

Table 2. Calculated values of affinity of various antibiotics to $\mathrm{His}_{6}-\mathrm{OPH}$ dimer and solvent accessible areas occupied by antibiotics and expressed as percentage of the total area of $\mathrm{His}_{6}$-OPH dimer. The area was calculated simultaneously for all the obtained models using PyMol functionality (get_area) with default settings.

\begin{tabular}{ccccccc}
\hline \multirow{2}{*}{ Antibiotic } & $\mathbf{p H}$ & \multicolumn{2}{c}{ Affinity $\left(\mathbf{k J} \cdot \mathbf{m o l}^{-\mathbf{1}}\right)$} & \multicolumn{2}{c}{ Area (\%) } \\
\cline { 3 - 7 } & & Mean & Median & Upper (Lower) Bounds & Near Active Sites & Total \\
\hline \multirow{2}{*}{ Ampicillin } & 7.5 & -28.61 & $-28.68 \pm 1.47$ & $-26.36(-30.54)$ & 5.2 & 11.8 \\
& 10.5 & -27.29 & $-27.00 \pm 1.25$ & $-25.94(-29.29)$ & 6.0 & 12.2 \\
\hline \multirow{2}{*}{ Gentamicin } & 7.5 & -27.32 & $-27.21 \pm 0.48$ & $-26.78(-28.03)$ & 6.8 & 11.5 \\
& 10.5 & -25.85 & $-25.75 \pm 1.16$ & $-23.85(-27.62)$ & 6.8 & 12.0 \\
\hline \multirow{2}{*}{ Kanamycin } & 7.5 & -26.83 & $-26.59 \pm 1.93$ & $-23.85(-29.71)$ & 7.0 & 11.8 \\
& 10.5 & -25.36 & $-24.91 \pm 1.71$ & $-23.85(-29.71)$ & 6.1 & 13.8 \\
\hline \multirow{2}{*}{ Rifampicin } & 7.5 & -29.90 & $-29.52 \pm 1.63$ & $-28.03(-33.05)$ & 8.7 & 12.6 \\
& 10.5 & -30.11 & $-29.73 \pm 1.44$ & $-28.45(-33.05)$ & 9.0 & 11.1 \\
\hline
\end{tabular}

The ratio of the solvent accessible area to the total surface of the $\mathrm{His}_{6}-\mathrm{OPH}$ dimer was evaluated for antibiotic-enzyme interaction at pH 7.5 and 10.5 (Table 2). The total solvent accessible area occupied by studied antibiotics was found to be independent of $\mathrm{pH}$. Also, the difference between the mean values $(11.9 \pm 0.5 \%$ and $12.3 \pm 1.1 \%$ at $\mathrm{pH} 7.5$ and 10.5 , respectively) was not statistically significant ( $p=0.587$ according to one-way ANOVA). Meanwhile, there was an uptrend in the percentage of occupied area near the active sites at both $\mathrm{pH}$ values within the series ampicillin $<$ gentamicin $\approx$ kanamycin $<$ rifampicin. To wit, an area blocked by ampicillin was smaller by a factor of 1.5-1.7 as compared to the case of rifampicin.

To prove the formation of the protein-inhibitor complexes, FTIR spectroscopy measurements were performed (Figure 6).

Based on the known specific characteristics [20] and the results of computer simulations, some structural moieties responsible for FTIR-spectra changes were assigned. Ampicillin had the following main bands lowered after mixing and interaction with $\mathrm{His}_{6}-\mathrm{OPH}$ : (1) $\mathrm{C}=\mathrm{O}$ stretching vibration of amide, carboxylic, and $\beta$-lactam group (ca. $1766 \mathrm{~cm}^{-1}$ ); (2) $\mathrm{C}=\mathrm{C}$ stretching vibration during deformation of benzene ring (ca. $1088 \mathrm{~cm}^{-1}$ ); (3) $\mathrm{C}-\mathrm{C}$ stretching vibration of several atoms within ring adjacent to lactam (ca. $990 \mathrm{~cm}^{-1}$ ); (4) several bending vibrations of hydrogens (more probably they were from among hydrogens bounded with benzene ring). Gentamicin and kanamycin had very similar patterns during interaction with $\mathrm{His}_{6}-\mathrm{OPH}$ : (1) $\mathrm{C}-\mathrm{C}$ stretching vibration within glycosides and streptamine (ca. $988 \mathrm{~cm}^{-1}$ ); (2) $\mathrm{C}-\mathrm{O}$ bending vibration in the glycosides and their binding with streptamine (ca. $1072 \mathrm{~cm}^{-1}$ ); (3) a lot of bending vibrations of hydrogens mainly bounded to glycosides and 
streptamine. Furthermore, kanamycin additionally had more pronounced decrease of $\mathrm{N}-\mathrm{H}$ bending vibration mode (ca. $1567 \mathrm{~cm}^{-1}$ ). Rifampicin had a decrease in $C=C$ stretching vibration (ca. $1721 \mathrm{~cm}^{-1}$ ) and $\mathrm{C}-\mathrm{H}$ bending vibration coupled with it $\left(\mathrm{ca} .1378 \mathrm{~cm}^{-1}\right)$. Besides, there were additional changes in several C-O and C-H bending vibrations (ca. $1064 \mathrm{~cm}^{-1}$ ), but it is not possible to discriminate between them. Most of the abovementioned alterations cannot be a result of catalytic action of $\mathrm{His}_{6}-\mathrm{OPH}$ and seem to argue in favor of some interactions between this enzyme and antibiotics.

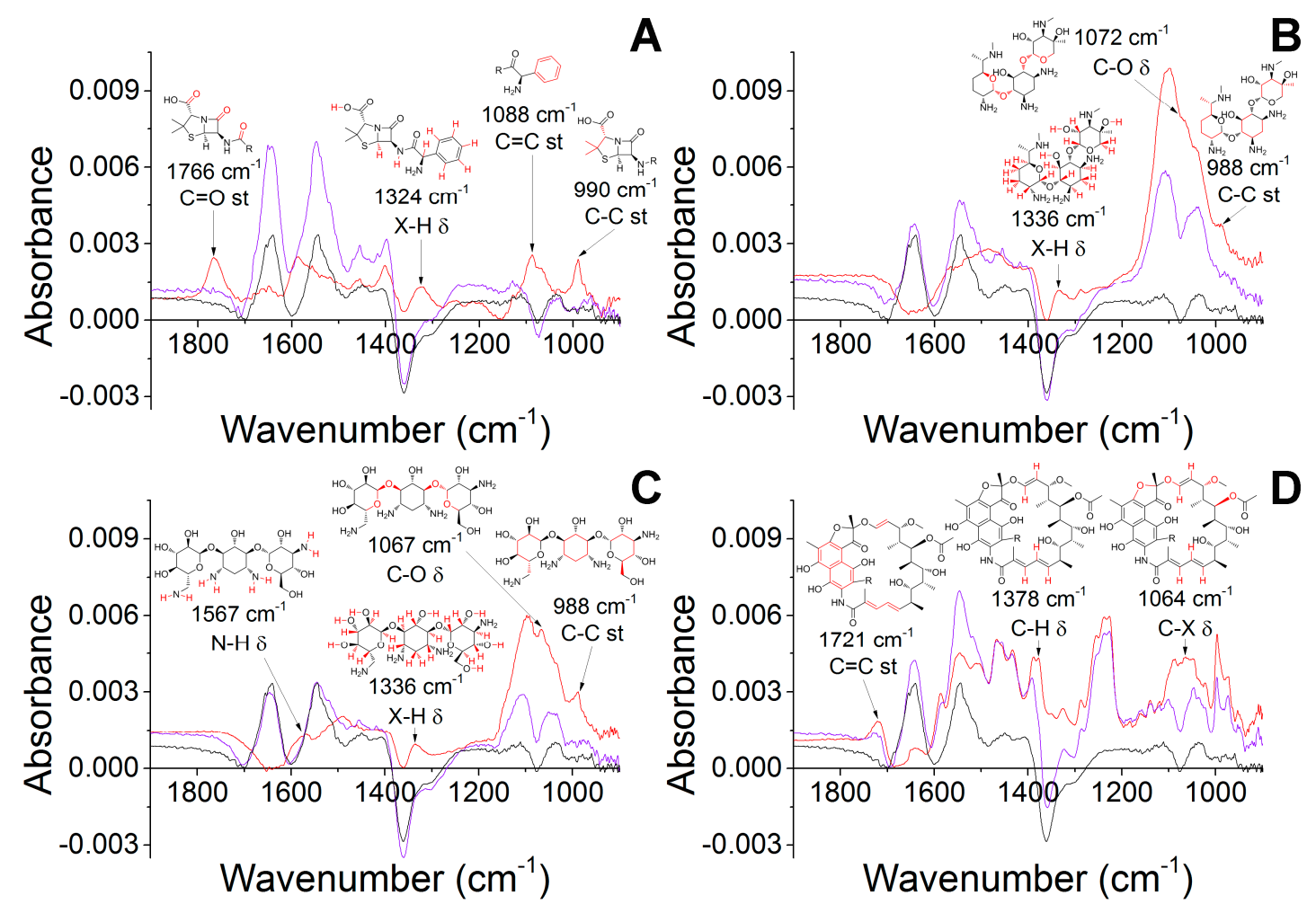

Figure 6. Fourier-transform infrared (FTIR) spectra of the studied samples. Violet line is for the enzyme, red is for the antibiotic, the black is for the antibiotic and enzyme (1:1). Concentration of each component in the samples was $1 \mathrm{~g} \cdot \mathrm{L}^{-1}$ : ampicillin-2.9 mM (A); gentamicin-2.1 mM (B); kanamycin-2.1 mM (C); and rifampicin-1.2 mM (D); $\mathrm{His}_{6}-\mathrm{OPH}-14 \mu \mathrm{M}$. Localization of some peaks is shown, and corresponding structural groups are emphasized with red. The following abbreviations are used: st—stretching vibration, $\delta$-deformation vibration, $X$-variable atom (see structure for details).

\subsection{The Influence of the Physico-Chemical Factors on the Lactonase Activity of $\mathrm{His}_{6}-\mathrm{OPH}$ in the Presence of Antibiotics}

The study of the lactonase activity of the enzyme during exposure at $\mathrm{pH} 7.4$ was of the greatest practical importance. This $\mathrm{pH}$ value is lower than $\mathrm{pH} 10.5$ that is optimal for the enzymatic activity of $\mathrm{His}_{6}-\mathrm{OPH}$, but it is close to that of the physiological conditions of live organisms.

Kinetics on the change in the enzyme activity at $37^{\circ} \mathrm{C}$ showed that after $8 \mathrm{~h}$ of combined exposure of the enzyme and antibiotics at $\mathrm{pH} 7.4$ the residual lactonase activity was greater than $50 \%$ of the initial value (Figure 7A). The greatest level of residual activity (70\%) was found in the presence of ampicillin. After $16 \mathrm{~h}$, the residual lactonase activity of $\mathrm{His}_{6}-\mathrm{OPH}$ was $9 \%$ higher for the case of rifampicin than that of the enzyme in the absence of antibiotics.

Thermostability of $\mathrm{His}_{6}-\mathrm{OPH}$ was increased also during short-term exposure to different temperatures (in the range $25-41{ }^{\circ} \mathrm{C}$ ) in the presence of antibiotics (Figure 7B). A usual room temperature was chosen as the lower bound, and the maximal temperature of the human body 
was applied as the upper bound. So, the presence of antibiotics with concentrations causing little inhibition of the enzyme had an essential stabilizing effect on the lactonase activity.
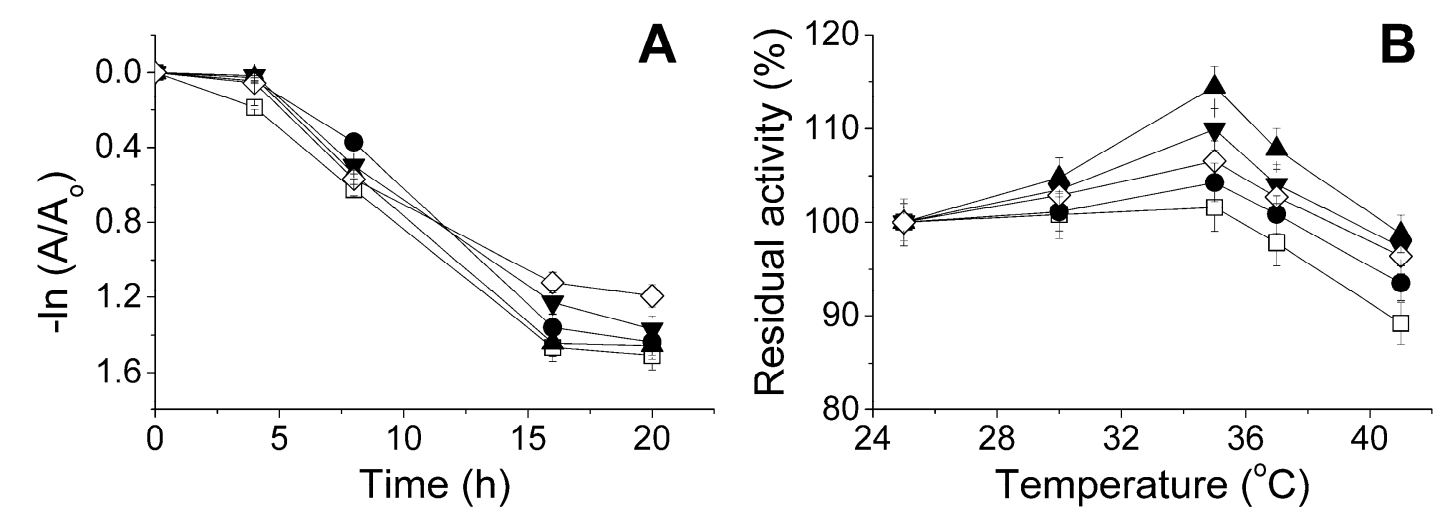

Figure 7. Thermal inactivation of lactonase activity of $\mathrm{His}_{6}-\mathrm{OPH}$ at $\mathrm{pH} 7.4$ as a function of (A) time of exposure at $37^{\circ} \mathrm{C}$; and (B) temperature of the environment upon exposure for $15 \mathrm{~min}$ in the absence $(\square)$ and presence of ampicillin $(\bullet)$, gentamicin $(\boldsymbol{\nabla})$, kanamycin $(\boldsymbol{\Delta})$, and rifampicin $(\diamond)$. Antibiotic and $\mathrm{His}_{6}-\mathrm{OPH}$ concentration were $0.2 \mathrm{~g} \cdot \mathrm{L}^{-1}$ and $0.1 \mathrm{~g} \cdot \mathrm{L}^{-1}$, respectively.

\section{Discussion}

A set of four well-known and widely-used antibiotics differing in chemical structure and mechanism of action was initially generated (Figure 8). Ampicillin, being a $\beta$-lactam antibiotic, is an irreversible inhibitor of transpeptidase, which participates in the synthesis of peptidoglycan of the pathogens' cell wall [21]. Rifampicin inhibits the DNA-dependent RNA polymerase [22]. Gentamicin and kanamycin, being aminoglycosides, bind to the bacterial ribosomal RNA (rRNA) (at the transcriptional RNA (tRNA) binding site), thus suppressing protein synthesis in pathogen cells [23].

One of the most important practical results of this study was that essential inhibition of the $\mathrm{His}_{6}-\mathrm{OPH}$ activity by antibiotics was pronounced at antibiotic concentration of $8-20 \mathrm{~g} \cdot \mathrm{L}^{-1}$, which is 5-20 times higher than the practically used therapeutic doses [24]. Another clearly positive result was the preservation of $50 \%$ of the lactonase activity upon $8 \mathrm{~h}$ of enzyme exposure at $37^{\circ} \mathrm{C}$ in an antibiotic-containing medium (at antibiotic concentration of $0.2 \mathrm{~g} \cdot \mathrm{L}^{-1}$ ). This time interval corresponds to the periodicity of application of many drugs for treatment of bacterial infections to support the minimum inhibitory concentration in the bloodstream [25]. So, the combined preparations prepared have good prospects.

The results concerning the inhibiting and stabilizing effect of antibiotics on the $\mathrm{His}_{6}-\mathrm{OPH}$ activity were important from both the scientific and practical standpoints. It is known that organic amines can be activators and competitive inhibitors of organophosphorus hydrolase [26]. Therefore, no initial assumptions could be made as to whether the studied amine-containing antibiotics had inhibiting or activating effect on the $\mathrm{His}_{6}-\mathrm{OPH}$. In this study, amine-containing antibiotics have been shown to possess an inhibiting effect on $\mathrm{His}_{6}-\mathrm{OPH}$ at high concentrations and a stabilizing effect at low concentrations. Such dualism seems to be common and can be triggered by multidirectional forces leading to the prevalence of one of them depending on conditions. 


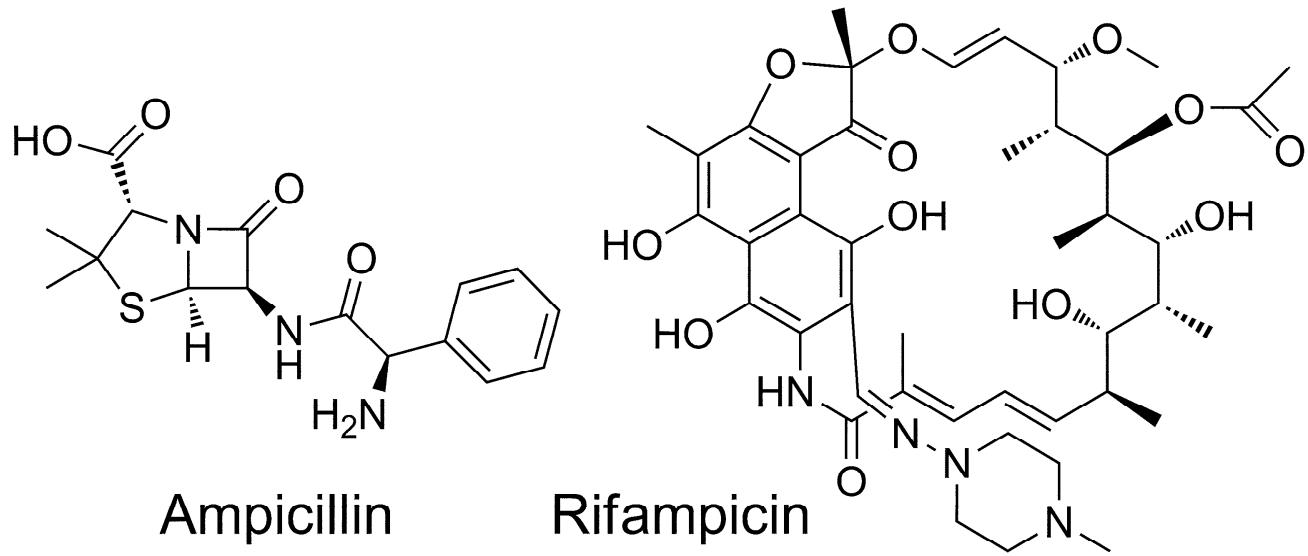<smiles>CN[C@H](C)[C@H]1CC[C@@H](N)[C@H](O[C@@H]2[C@@H](N)C[C@@H](N)[C@H](O[C@@H]3OC[C@](C)(O)[C@H](NC)[C@H]3O)[C@H]2O)O1</smiles>

Gentamicin

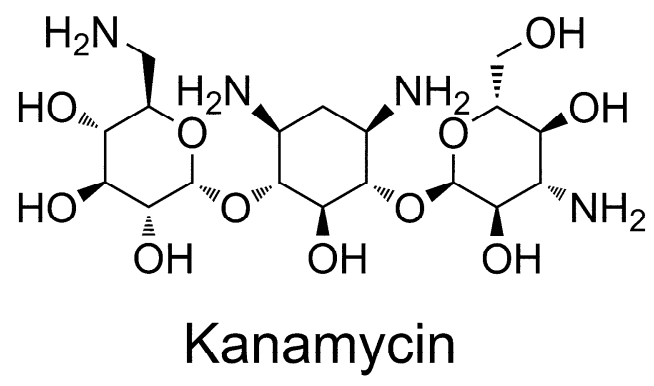

Figure 8. Chemical structures of antibiotics used in this study.

Rifampicin was the strongest inhibitor of $\mathrm{His}_{6}-\mathrm{OPH}$ among the antibiotics used in this study (Table 1). In full compliance with this, rifampicin occupied the largest area near active centers of the enzyme (Figure 5, Table 2). Also, it had minimal energy of binding, i.e., its binding was preferred from a thermodynamic standpoint. In contrast to this, ampicillin had the lowest inhibiting effect on the enzyme and smallest area occupied near active centers. Aminoglycosides (gentamicin and kanamycin) had both intermediate values of inhibition constants and occupied areas nearer to active centers relative to those of the two former antibiotics. So, inhibition potency correlated with results of molecular docking in terms of localization of binding modes. A less positive situation was for energies of binding of ampicillin, gentamicin, and kanamycin, and no correlation was observed. Possibly, both factors (localization and energy) should be taken into account simultaneously.

Also, the computer simulation performed in this study does not allow for discrimination between the competitive and uncompetitive inhibition and, thus, the evaluation of the contribution of each one to the antibiotic-enzyme interaction. However, this problem can be potentially solved via a more precise calculation of the binding energy for the antibiotic using the reliable quantum mechanical/molecular mechanical (QM/MM) [27] or QM/MM/molecular dynamical techniques [28].

Being the strongest inhibitor of $\mathrm{His}_{6}-\mathrm{OPH}$ withits $\mathrm{EPC}$ at high concentrations, rifampicin at low concentration $\left(0.2 \mathrm{~g} \cdot \mathrm{L}^{-1}\right)$ had the greatest stabilizing effect and allowed preservation of the maximum lactonase activity upon long exposure at $37^{\circ} \mathrm{C}$ (Figure 7B). On the other hand, combining ampicillin with $\mathrm{His}_{6}-\mathrm{OPH}$ and its EPC produced the most active and stable catalytic agents (Table 1).

The interaction between the enzyme and antibiotics was confirmed via FTIR spectroscopy (Figure 6). A change in the intensity of some bands for antibiotics was observed when they were present in the medium with $\mathrm{His}_{6}-\mathrm{OPH}$. These changes differ on the antibiotic used; while ampicillin seemed to be able to form hydrogen bonds via $\mathrm{C}=\mathrm{O}$ groups and pure hydrophobic coupling of the benzene ring, rifampicin leant only on hydrophobic interactions via several points (naphthalene ring and/or alkenyl groups). Apart from them were gentamicin and kanamycin; both had a decreased mobility of the glycoside and/or streptamine rings due to hydrophobic interactions, but kanamycin seemed to form additionally a hydrogen bond(s) by its amino group(s). Such a difference may be 
due to amino groups of kanamycin are located on the same side of the molecule (like $\mathrm{C}=\mathrm{O}$ groups in ampicillin), while the same ones are split fifty-fifty in gentamicin.

Interestingly, other researchers have previously shown inhibition of the paraoxon-hydrolyzing enzyme (human paraoxonase 1, PON1) by antibiotics, including ampicillin $\left(\mathrm{IC}_{50}=85.9 \mathrm{mM}\right.$ ), gentamicin $\left(\mathrm{IC}_{50}=1.26 \mathrm{mM}\right)$, and kanamycin $\left(\mathrm{IC}_{50}=1.24 \mathrm{mM}\right)$ [29]. That is, having a similar activity pattern as $\mathrm{His}_{6}-\mathrm{OPH}$ and being suggested as another prospective quorum quenching enzyme [7], PON1 seems to be much more sensitive to inhibition by such common antibiotics. Thus, $\mathrm{His}_{6}-\mathrm{OPH}$ has additional catalytic advantages as compared to PON1. Moreover, being more biotechnologically advanced, $\mathrm{His}_{6}-\mathrm{OPH}$ may be a better active compound in the combined preparations with antibiotics.

\section{Materials and Methods}

\subsection{Materials}

The poly-L-glutamic acid sodium salt $\left(\mathrm{PLE}_{50}\right.$, molecular weight $\left.(\mathrm{MW})=7.5 \mathrm{~kg} \cdot \mathrm{mol}^{-1}\right)$ and poly-L-aspartic acid sodium salt $\left(\mathrm{PLD}_{50}, \mathrm{MW}=6.8 \mathrm{~kg} \cdot \mathrm{mol}^{-1}\right.$ ) (Alamanda Polymers, Huntsville, AL, USA) were used for production of polyelectrolyte complexes of $\mathrm{His}_{6}-\mathrm{OPH}$. Antibiotics (ampicillin, gentamicin sulfate, kanamycin sulfate, and rifampicin), L-homoserine lactone hydrochloride (HSL), paraoxon, and other reagents were purchased from Sigma (Saint Louis, MO, USA). Recombinant Escherichia coli strain SG13009[pREP4] (Qiagen, Hilden, Germany) transformed by plasmid encoding $\mathrm{His}_{6}-\mathrm{OPH}[30]$ was used for $\mathrm{His}_{6}-\mathrm{OPH}$ production.

\subsection{Preparation of Enzyme Samples}

Recombinant cells of Escherichia coli SG13009[pREP4] were cultivated, and the enzyme was isolated and purified by methods published previously [31]. The purified preparation of $\mathrm{His}_{6}-\mathrm{OPH}$ was characterized by enzymatic activity as described earlier [17]. The concentration of protein was determined by Bradford assay, and protein purity was analyzed by SDS-PAGE in $12 \%$ polyacrylamide gel using Mini-PROTEAN II cell (Bio-Rad, Hercules, CA, USA) followed by Coomassie Blue (R-250) staining. According to SDS-PAGE (data not shown), the purity of $\mathrm{His}_{6}-\mathrm{OPH}$ preparation obtained $\left(\mathrm{MW} \approx 37 \mathrm{~kg} \cdot \mathrm{mol}^{-1}\right)$ was ca. $98 \%$. The specific organophosphorus hydrolase activity of the purified enzyme was $4300 \mathrm{U} \cdot \mathrm{mg}^{-1}$. One unit of enzymatic activity (U) was defined as the quantity of the enzyme necessary to hydrolyze $1 \mu \mathrm{mol}$ of Paraoxon per min at $25^{\circ} \mathrm{C}$.

\subsection{Preparation of Enzyme-Polyelectrolyte Complexes}

EPCs were produced similarly to the known procedure [19]. To produce an EPC ( $\mathrm{His}_{6}-\mathrm{OPH} / \mathrm{PLE}_{50}$ and $\left.\mathrm{His}_{6}-\mathrm{OPH} / \mathrm{PLD}_{50}\right)$, an aliquot of $20 \mathrm{~g} \cdot \mathrm{L}^{-1} \mathrm{PLE}_{50}$ or $\mathrm{PLD}_{50}$ water solution was added to the purified His $_{6}$-OPH $\left(1.6 \pm 0.1 \mathrm{~g} \cdot \mathrm{L}^{-1}\right)$ in $50 \mathrm{mM}$ phosphate buffer (pH 7.5) containing $150 \mathrm{mM} \mathrm{NaCl}$. The aliquot volume was calculated so that "enzyme: polymer" molar ratio was 1:5. Next, the mixture was held for $30 \mathrm{~min}$ at $8{ }^{\circ} \mathrm{C}$. The effective hydrodynamic diameter of the particles of prepared complexes was determined at $25^{\circ} \mathrm{C}$ by dynamic light scattering using a Zetasizer Nano ZS (Malvern Instruments Ltd., Malvern, UK) as it was published previously [19] and was equal to $35 \pm 5 \mathrm{~nm}$.

\subsection{Measurement of Enzyme Activity}

The organophosphorus hydrolase activity was determined as described earlier [17] with $7.7 \mathrm{mM}$ aqueous Paraoxon stock solution at $405 \mathrm{~nm}$ using the Agilent $8453 \mathrm{UV}$-visible spectroscopy system (Agilent Technology, Waldbronn, Germany) equipped with a thermostatted analytical cell. The reaction was carried out in a $0.1 \mathrm{M}$ carbonate buffer $\left(\mathrm{pH}\right.$ 10.5). Concentration of $\mathrm{His}_{6}-\mathrm{OPH}$ in the reaction cuvette was $2.5 \times 10^{-9} \mathrm{M}$.

Initial solutions of antibiotics were prepared at concentration of $30-40 \mathrm{~g} \cdot \mathrm{L}^{-1}(114 \mathrm{mM}$ ampicillin, $83 \mathrm{mM}$ gentamicin, $62 \mathrm{mM}$ kanamycin, and $36 \mathrm{mM}$ rifampicin) in $50 \mathrm{mM}$ phosphate buffer (pH 7.4), containing $50 \mathrm{mM} \mathrm{NaHCO}_{3}$. Antimicrobial and enzyme agents were mixed in $50 \mathrm{mM}$ phosphate buffer 
(pH 7.4), containing $50 \mathrm{mM} \mathrm{NaHCO}_{3}$ and $150 \mathrm{mM} \mathrm{NaCl}$, and exposed for $30 \mathrm{~min}$ at room temperature. Usually, concentration of $\mathrm{His}_{6}-\mathrm{OPH}$ in the medium was $0.4 \mathrm{~g} \cdot \mathrm{L}^{-1}$, i.e., $5.6 \mu \mathrm{M}$. Thereupon the measurements of enzymatic activity were performed as described above.

The lactonase activity was determined spectrophotometrically according to the known method using a pH-sensitive indicator cresol red [32]. The analysis was performed in a $2.5 \mathrm{mM}$ Bicine buffer (pH 8.2) containing $0.1 \mathrm{M} \mathrm{NaCl}$. One unit of enzymatic lactonase activity (U) was defined as the quantity of the enzyme necessary to hydrolyze $1 \mu \mathrm{mol}$ of $\mathrm{N}$-(3-oxododecyl)-L-homoserine lactone per min at $25^{\circ} \mathrm{C}$. Such a substrate was chosen as the best one on the basis of previously obtained results [16].

During lactonase activity tests, antibiotic concentration in the medium was $0.2 \mathrm{~g} \cdot \mathrm{L}^{-1}$ (0.58 $\mathrm{mM}$ ampicillin, $0.42 \mathrm{mM}$ gentamicin, $0.42 \mathrm{mM}$ kanamycin, and $0.24 \mathrm{mM}$ rifampicin), and $\mathrm{His}_{6}-\mathrm{OPH}$ concentration was $0.1 \mathrm{~g} \cdot \mathrm{L}^{-1}(1.4 \mu \mathrm{M})$. Mixtures were exposed at $25-41{ }^{\circ} \mathrm{C}$ and $\mathrm{pH} 7.4$ for $15 \mathrm{~min}$ and then cooled, and residual activity was measured. Kinetics of thermoinactivation was issued at $37^{\circ} \mathrm{C}$ and $\mathrm{pH} 7.4$ by periodic sampling and measuring the residual activity.

The values of Michaelis constant $\left(K_{\mathrm{m}}\right)$, apparent Michaelis constant $\left(K_{\mathrm{m}}{ }^{\text {app }}\right)$, the maximum rate of enzymatic reaction $\left(V_{\max }\right)$, and apparent maximum rate of enzymatic reaction $\left(V_{\max }{ }^{\text {app }}\right)$ were determined by hyperbolic approximation using the least square method in Origin Pro (ver. 8.1 SR3, OriginLab, Northampton, MA, USA). Competitive $\left(K_{\mathrm{ic}}\right)$ and uncompetitive $\left(K_{\mathrm{iu}}\right)$ inhibition constants were calculated with Dixon plot using the same program.

The data are presented as means of at least three independent experiments \pm standard deviation $( \pm \mathrm{SD})$. Statistical analysis was realized using SigmaPlot (ver. 12.5, Systat Software Inc., San Jose, CA, USA).

\subsection{FTIR Spectroscopy}

In order to obtain FTIR absorption spectra, samples containing pure antibiotic or pure enzyme or a mixture of enzyme and antibiotic were prepared. The $2 \mathrm{~g} \cdot \mathrm{L}^{-1}$ solution of antibiotic (5.8 $\mathrm{mM}$ ampicillin, $4.2 \mathrm{mM}$ gentamicin, $4.2 \mathrm{mM}$ kanamycin, or $2.4 \mathrm{mM}$ rifampicin) and the $2 \mathrm{~g} \cdot \mathrm{L}^{-1}$ solution of enzyme $(28 \mu \mathrm{M})$ were mixed in 1:1 volumetric proportion in $50 \mathrm{mM}$ phosphate buffer $(\mathrm{pH} 7.4)$ containing $50 \mathrm{mM} \mathrm{NaHCO}_{3}$ and filtered through $0.2 \mu \mathrm{m}$-filter. The influence of the environment factors on the intensity of the spectra was minimized. The measuring chamber was first cleaned and checked for impurities by recording the FTIR spectrum of water. All the analytical solutions were prepared from identical initial components and under identical conditions. The FTIR spectra were recorded with a Fourier IR spectrometer (Tensor 27, Bruker, Bremen, Germany), equipped with a liquid nitrogen-cooled mercury-cadmium-telluride (MCT) detector and Ministat 125 thermostat (Huber, Cary, NC, USA). The measurements were performed in a thermostatted FTIR (frustrated total internal reflection) cell (BioATR-II, Bruker, Bremen, Germany) using a single-reflection crystal ZnSe at $22^{\circ} \mathrm{C}$ and constant rate of dry-air flow provided with a Jun-Air compressor (Gast Manufacturing Inc., Benton Harbor, MI, USA). An aliquot $(50 \mu \mathrm{L})$ of the sample was applied on the FTIR cell's crystal, the spectrum was recorded thrice in the range of $4000 \mathrm{~cm}^{-1}$ to $950 \mathrm{~cm}^{-1}$, with $1 \mathrm{~cm}^{-1}$ resolution; 70-pass scanning and averaging was performed. The background spectrum was recorded in a similar way for a buffer alone. The spectra were analyzed with Opus software (ver. 7.0, Bruker, Bremen, Germany).

\subsection{Computer Simulations}

The structures of the antibiotics were created using ChemBioDraw software (ver. 12.0, CambridgeSoft, Cambridgeshire, UK). After that, energy minimization using ChemBio3D with force field MM2 was applied. Finally, the structures in protein data bank (PDB) format were converted to the PDBQT format (PDB format with partial charges and atom types) using AutoDockTools (as part of MGLTools ver. 1.5.6, available at http:/ / mgltools.scripps.edu/) [33] with atomic charges calculated with the Gasteiger-Marsili method.

To calculate the surface charge distribution of $\mathrm{His}_{6}-\mathrm{OPH}$ at a certain $\mathrm{pH}$, adaptive Poisson-Boltzmann solver (APBS) and PDB2PQR servers (ver. 1.4.2.1 and 2.1.1, respectively, available at 
http:/ /www.poissonboltzmann.org/) with PARSE forcefield and default settings were used [34,35]. As a basis, known crystallographic structure of OPH dimer (PDB number 1QW7) was used with preliminary modification by $\mathrm{His}_{6}$-tag as described previously [36].

The dockings of ligands to the differently protonated $\mathrm{His}_{6}-\mathrm{OPH}$ dimer were realized using AutoDock Vina (ver. 1.1.2, available at http:/ / vina.scripps.edu/) [37] on a desktop computer equipped with Intel Pentium Dual-Core central processing unit (CPU) E5400 $2.7 \mathrm{GHz}$ and 3 GB of available memory. Briefly, the grid box was approximately centered on the center of mass of the $\mathrm{His}_{6}-\mathrm{OPH}$ dimer. The size of the grid box was chosen so that any enzyme surface was within the box with an additional margin (overall volume was ca. $360 \mathrm{~nm}^{3}$; compared with the volume of the OPH dimer of less than $220 \mathrm{~nm}^{3}$, see PDB number 1QW7 for details). Calculations were performed with default program options.

Vibration modes of energy-minimized antibiotics were simulated using the GAMESS-US package (ver. 2017 R1) [38] under unrestricted Hartree-Fock calculation with hybrid generalized gradient approximations of density functional theory (B3LYP) and basis $6-31 G^{*}$. Single $p$-type polarization functions on hydrogens under Huzinaga assumption and diffusion of $s$ shell to hydrogens were applied. Pipek-Mezey population localization of orbitals was used. Calculations were performed with Supercomputer "Lomonosov" of Lomonosov Moscow State University [39] utilizing up to 64 Intel Xeon X5570 2.93GHz and Intel MPI Library (ver. 5.0.1, Intel, Santa Clara, CA, USA).

\section{Conclusions}

The influence of various antibiotics on the activity of $\mathrm{His}_{6}-\mathrm{OPH}$ was studied. These antibiotics were found to be stabilizers and, at the same time, substances provoking mixed inhibition. Depending on antibiotic concentration, the contribution of each mode is different, and stabilization is profound at low concentrations, while inhibition prevails at high concentrations. Differences were due to the antibiotics binding to the $\mathrm{His}_{6}-\mathrm{OPH}$ in varying ways and degrees. A $\beta$-lactam antibiotic ampicillin proved to be the best choice for combining with this enzyme and its polyelectrolyte complex $\left(\mathrm{His}_{6}-\mathrm{OPH} / \mathrm{PLD}_{50}\right)$. This combination seems to be a good prospect for further studies on controlling the population of gram-negative bacteria, including those resistant to the antibiotic alone.

Besides, a good correlation of the molecular docking results with those of the experiment allows us to conclude that this approach has a great potential for looking for effective combinations of the enzyme and antibiotics. This technique can be further used for virtual screening of known antibiotics as possible partners for "bacterial quorum quenching" enzymes in order to achieve a qualitative enhancement of the characteristics of the combined preparations based on these enzymes.

Acknowledgments: This work was supported by the Russian Science Foundation [Grant No.16-14-00061].

Author Contributions: O.M., N.S., and E.E. conceived and designed the experiments; A.A. and N.S. performed the experiments; I.L. realized the molecular docking; O.M., A.A., N.S., I.L., and E.E. analyzed the data and wrote the paper.

Conflicts of Interest: The authors declare no conflict of interest.

\section{References}

1. Van Wyk, H. Antibiotic resistance. S. Afr. Pharm. J. 2015, 82, 20-23.

2. Worthington, R.J.; Melander, C. Combination approaches to combat multidrug-resistant bacteria. Trends Biotechnol. 2013, 31, 177-184. [CrossRef] [PubMed]

3. Høiby, N.; Bjarnsholt, T.; Givskov, M.; Molin, S.; Ciofu, O. Antibiotic resistance of bacterial biofilms. Int. J. Antimicrob. Agents 2010, 35, 322-332. [CrossRef] [PubMed]

4. Lazar, V. Quorum sensing in biofilms-How to destroy the bacterial citadels or their cohesion/power? Anaerobe 2011, 17, 280-285. [CrossRef] [PubMed]

5. Algburi, A.; Comito, N.; Kashtanov, D.; Dicks, L.M.; Chikindas, M.L. Control of biofilm formation: Antibiotics and beyond. Appl. Environ. Microbiol. 2017, 83. [CrossRef] 
6. Hong, K.W.; Koh, C.L.; Sam, C.K.; Yin, W.F.; Chan, K.G. Quorum quenching revisited—From signal decays to signalling confusion. Sensors 2012, 12, 4661-4696. [CrossRef] [PubMed]

7. Li, X.C.; Wang, C.; Mulchandani, A.; Ge, X. Engineering soluble human paraoxonase 2 for quorum quenching. ACS Chem. Biol. 2016, 11, 3122-3131. [CrossRef] [PubMed]

8. Teplitski, M.; Mathesius, U.; Rumbaugh, K.P. Perception and degradation of N-acyl homoserine lactone quorum sensing signals by mammalian and plant cells. Chem. Rev. 2010, 111, 100-116. [CrossRef] [PubMed]

9. Kiran, S.; Sharma, P.; Harjai, K.; Capalash, N. Enzymatic quorum quenching increases antibiotic susceptibility of multidrug resistant Pseudomonas aeruginosa. Iran. J. Microbiol. 2011, 3, 1-12. [PubMed]

10. Amara, N.; Krom, B.P.; Kaufmann, G.F.; Meijler, M.M. Macromolecular inhibition of quorum sensing: Enzymes, antibodies, and beyond. Chem. Rev. 2010, 111, 195-208. [CrossRef] [PubMed]

11. Kalia, V.C.; Raju, S.C.; Purohit, H.J. Genomic analysis reveals versatile organisms for quorum quenching enzymes: Acyl-homoserine lactone-acylase and -lactonase. Open Microbiol. J. 2011, 5, 1-13. [CrossRef] [PubMed]

12. Hiblot, J.; Bzdrenga, J.; Champion, C.; Chabriere, E.; Elias, M. Crystal structure of VmoLac, a tentative quorum quenching lactonase from the extremophilic crenarchaeon Vulcanisaeta moutnovskia. Sci. Rep. 2015, 5, 8372. [CrossRef] [PubMed]

13. Mascarenhas, R.; Thomas, P.W.; Wu, C.X.; Nocek, B.P.; Hoang, Q.Q.; Liu, D.; Fast, W. Structural and biochemical characterization of AidC, a quorum-quenching lactonase with atypical selectivity. Biochemistry 2015, 54, 4342-4353. [CrossRef] [PubMed]

14. Uroz, S.; Oger, P.M.; Chapelle, E.; Adeline, M.T.; Faure, D.; Dessaux, Y. A Rhodococcus qsdA-encoded enzyme defines a novel class of large-spectrum quorum-quenching lactonases. Appl. Environ. Microbiol. 2008, 74, 1357-1366. [CrossRef] [PubMed]

15. Wang, L.H.; Weng, L.X.; Dong, Y.H.; Zhang, L.H. Specificity and enzyme kinetics of the quorum-quenching $\mathrm{N}$-acyl homoserine lactone lactonase (AHL-lactonase). J. Biol. Chem. 2004, 279, 13645-13651. [CrossRef] [PubMed]

16. Sirotkina, M.; Efremenko, E.N. Rhodococcus lactonase with organophosphate hydrolase (OPH) activity and $\mathrm{His}_{6}$-tagged $\mathrm{OPH}$ with lactonase activity: evolutionary proximity of the enzymes and new possibilities in their application. Appl. Microbiol. Biotechnol. 2014, 98, 2647-2656. [CrossRef] [PubMed]

17. Votchitseva, Y.A.; Efremenko, E.N.; Aliev, T.K.; Varfolomeyev, S.D. Properties of hexahistidine-tagged organophosphate hydrolase. Biochemistry (Moscow) 2006, 71, 167-172. [CrossRef] [PubMed]

18. Lyagin, I.V.; Andrianova, M.S.; Efremenko, E.N. Extensive hydrolysis of phosphonates as unexpected behaviour of the known $\mathrm{His}_{6}$-organophosphorus hydrolase. Appl. Microbiol. Biotechnol. 2016, 100, 5829-5838. [CrossRef] [PubMed]

19. Efremenko, E.N.; Lyagin, I.V.; Klyachko, N.L.; Bronich, T.; Zavyalova, N.V.; Jiang, Y.; Kabanov, A.V. A simple and highly effective catalytic nanozyme scavenger for organophosphorus neurotoxins. J. Control. Release 2017, 247, 175-187. [CrossRef] [PubMed]

20. Pretsch, E.; Bühlman, P.; Badertscher, M. Structure Determination of Organic Compounds: Tables of Spectral Data, 4th ed.; Springer: Berlin, Germany, 2009; pp. 269-335. ISBN 978-3-540-93809-5.

21. Hooper, D.C. Mechanisms of action of antimicrobials: Focus on fluoroquinolones. Clin. Infect. Dis. 2001, 32, S9-S15. [CrossRef] [PubMed]

22. Floss, H.G.; Yu, T.W. Rifamycin mode of action, resistance, and biosynthesis. Chem. Rev. 2005, 105, 621-632. [CrossRef] [PubMed]

23. Kotra, L.P.; Haddad, J.; Mobashery, S. Aminoglycosides: Perspectives on mechanisms of action and resistance and strategies to counter resistance. Antimicrob. Agents Chemother. 2000, 44, 3249-3256. [CrossRef] [PubMed]

24. Van Bambeke, F.; Barcia-Macay, M.; Lemaire, S.; Tulkens, P.M. Cellular pharmacodynamics and pharmacokinetics of antibiotics: Current views and perspectives. Curr. Opin. Drug Discov. Dev. 2006, 9, 218-230.

25. Leekha, S.; Terrell, C.L.; Edson, R.S. General principles of antimicrobial therapy. Mayo Clin. Proc. 2011, 86, 156-167. [CrossRef] [PubMed]

26. Sergeeva, V.S.; Efremenko, E.N.; Kazankov, G.M.; Varfolomeyev, S.D. Double effect of organic amines (activation and inhibition) on the phosphotriesterase. J. Mol. Catal. B Enzym. 2000, 10, 571-576. [CrossRef] 
27. Chaskar, P.; Zoete, V.; Röhrig, U.F. Toward on-the-fly quantum mechanical/molecular mechanical (QM/MM) docking: Development and benchmark of a scoring function. J. Chem. Inf. Model. 2014, 54, 3137-3152. [CrossRef] [PubMed]

28. Nowosielski, M.; Hoffmann, M.; Kuron, A.; Korycka-Machala, M.; Dziadek, J. The MM2QM tool for combining docking, molecular dynamics, molecular mechanics, and quantum mechanics. J. Comput. Chem. 2013, 34, 750-756. [CrossRef] [PubMed]

29. Samra, Z.Q.; Shabir, S.; Rehmat, Z.; Zaman, M.; Nazir, A.; Dar, N.; Athar, M.A. Synthesis of cholesterol-conjugated magnetic nanoparticles for purification of human paraoxonase 1 . Appl. Biochem. Biotechnol. 2010, 162, 671-686. [CrossRef] [PubMed]

30. Efremenko, E.N.; Votchitseva, Y.A.; Aliev, T.K.; Varfolomeev, S.D. Recombinant Plasmid DNA pTES-HIS-OPH and Producer of Oligohistidine-Containing Organophosphate Hydrolase. RU Patent 2255975 C 1, 10 July 2005.

31. Efremenko, E.; Votchitseva, Y.; Plieva, F.; Galaev, I.; Mattiasson, B. Purification of His 6 -organophosphate hydrolase using monolithic supermacroporous polyacrylamide cryogels developed for immobilized metal affinity chromatography. Appl. Microbiol. Biotechnol. 2006, 70, 558-563. [CrossRef] [PubMed]

32. Freeman, L.; Buisson, M.; Tarbouriech, N.; Van der Heyden, A.; Labbé, P.; Burmeister, W.P. The flexible motif $\mathrm{V}$ of Epstein-Barr virus deoxyuridine $5^{\prime}$-triphosphate pyrophosphatase is essential for catalysis. J. Biol. Chem. 2009, 284, 25280-25289. [CrossRef] [PubMed]

33. Morris, G.M.; Huey, R.; Lindstrom, W.; Sanner, M.F.; Belew, R.K.; Goodsell, D.S.; Olson, A.J. AutoDock4 and AutoDockTools4: Automated docking with selective receptor flexibility. J. Comput. Chem. 2009, 16, 2785-2791. [CrossRef] [PubMed]

34. Baker, N.A.; Sept, D.; Joseph, S.; Holst, M.J.; McCammon, J.A. Electrostatics of nanosystems: Application to microtubules and the ribosome. Proc. Natl. Acad. Sci. USA 2001, 98, 10037-10041. [CrossRef] [PubMed]

35. Dolinsky, T.J.; Czodrowski, P.; Li, H.; Nielsen, J.E.; Jensen, J.H.; Klebe, G.; Baker, N.A. PDB2PQR: Expanding and upgrading automated preparation of biomolecular structures for molecular simulations. Nucleic Acids Res. 2007, 35, W522-W525. [CrossRef] [PubMed]

36. Efremenko, E.N.; Lyagin, I.V.; Le, H.C.; Le, M.H. Antioxidants as stabilizers for His $_{6}-\mathrm{OPH}$ : Is this an unusual or regular role for them with enzymes? J. Biochem. 2017. [CrossRef] [PubMed]

37. Trott, O.; Olson, A.J. AutoDock Vina: Improving the speed and accuracy of docking with a new scoring function, efficient optimization, and multithreading. J. Comput. Chem. 2010, 31, 455-461. [CrossRef] [PubMed]

38. Schmidt, M.W.; Baldridge, K.K.; Boatz, J.A.; Elbert, S.T.; Gordon, M.S.; Jensen, J.H.; Koseki, S.; Matsunaga, N.; Nguyen, K.A.; Su, S.; et al. General atomic and molecular electronic structure system. J. Comput. Chem. 1993, 14, 1347-1363. [CrossRef]

39. Sadovnichy, V.; Tikhonravov, A.; Voevodin, V.; Opanasenko, V. “Lomonosov": Supercomputing at Moscow State University. In Contemporary High Performance Computing: From Petascale toward Exascale; Vetter, J.S., Ed.; Chapman \& Hall/CRC Computational Science Series; CRC Press: Boca Raton, FL, USA, 2013; pp. $283-307$. ISBN 9781466568341.

(C) 2017 by the authors. Licensee MDPI, Basel, Switzerland. This article is an open access article distributed under the terms and conditions of the Creative Commons Attribution (CC BY) license (http:/ / creativecommons.org/licenses/by/4.0/). 